\title{
Perceptions About the WTO Trade Institutions
}

John H. Jackson

Georgetown University Law Center, jacksojh@law.georgetown.edu

Copyright @ 2002 Cambridge University Press; http://journals.cambridge.org/action/ displayJournal?jid=WTR

This paper can be downloaded free of charge from:

https://scholarship.law.georgetown.edu/facpub/587

1 World Trade Rev. 101-114 (2002)

This open-access article is brought to you by the Georgetown Law Library. Posted with permission of the author. Follow this and additional works at: https://scholarship.law.georgetown.edu/facpub

Part of the Dispute Resolution and Arbitration Commons, and the International Trade Law Commons 


\title{
Perceptions about the WTO trade institutions
}

\author{
JOHN H. JACKSON* \\ Georgetown University Law Centre
}

\begin{abstract}
This article, based on a lecture given at the inauguration ceremony for the new Advisory Centre on WTO Law, describes the broader world trading landscape into which this new Centre emerges. Taking into account the possible implications of the events on September 11, this article provides a brief analysis of the current trade policy climate, asserting the necessity of institutions for the successful functioning of markets. After a short institutional history of the GATT/WTO, the author describes the importance of institutional rules, treaty text, and practice for the success of the WTO and presents the current debate over what the scope of this institution has been, is now, and could be in the future - the debate over which important issues should be taken under the WTO umbrella, and, further, which issues are appropriate to send to the Dispute Settlement System. Finally, this article illustrates the challenges facing this dispute settlement system, proposals for reform, and the vital role that the new Advisory Centre may be able to play in resolving some of these challenges.
\end{abstract}

The ceremony for the inauguration of the newly formed Advisory Centre on WTO Law, which will fulfill a vitally needed role for giving assistance to developing countries in their activities in the WTO dispute settlement system, is an appropriate context for me to address some of the broader issues of the WTO, and to situate the beginning of this new Advisory Centre in that broader context. ${ }^{1}$ It is my intention to do this task in four major parts. First I will discuss the broader policy 'landscape' in which the trade system is situated today, recognizing that the events of 11 September in New York City and Washington DC are having an extraordinarily profound impact, but not focusing solely on that feature.

Secondly, in section 2, I will discuss the WTO as an institution and the importance of the institutional rules, treaty text, and practice for the success of the WTO and other organizations related to it. In this part, I will focus primarily on the nondispute settlement features of the organization, namely the diplomatic and

* Correspondence: University Professor of Law, Georgetown University Law Centre, 600 New Jersey Avenue, NW, Washington DC 20001, USA.

1 This article is adapted from my keynote lecture delivered at the ceremony for the inauguration of the Advisory Centre on WTO Law, held in Geneva at the WTO, on 5 October 2001. The talk was delivered from rough notes, and was not recorded, so this article is partially a reconstruction as well as a subsequent editing and abridgement of that talk. 
negotiating contexts that make various decisions and are creating rules or rule changes.

In section 3, I will turn to the dispute settlement system, looking at its institutional role in the context of the broader 'constitution'. And, finally, in section 4, I will turn to the new Advisory Centre, and its significance in this broader context.

\section{The current policy landscape of the WTO trading system}

\subsection{The meaning of 11 September and after}

It is not possible to avoid the implications of what happened in New York City and Washington DC on 11 September.

In the United States, virtually every citizen knows the date of 7 December 1941. On that date, Pearl Harbor was attacked without warning by a foreign government's military power, and it resulted in the United States essentially losing a major Navy Fleet. Approximately 2,400 persons (virtually all military personnel) died in that attack.

On 11 September 2001, in New York City, several terrorist-hijacked airplanes attacked a symbol of western democratic institutions - the World Trade Centre - in the heart of the New York trade and financial center. Over 3,000 persons (virtually all non-military) lost their lives in this attack (and in another attack in Washington DC) and the World Trade Centre itself was destroyed, inflicting potentially severe damage on the entire world economy.

Thus, we can make some comparisons between these events, and it would not be folly to come to the judgment that the more recent event was several times more severe and disastrous than the previous one mentioned. Already we are seeing a variety of commentary and discussion about the impact of the September events. For example, there are those who say that this is the end of globalization, although there are other comments that oppose that. Among other things, we have seen major economic sectors, such as travel (particularly air travel) and tourism, plummet, resulting in more than 100,000 job losses in airlines, and potentially many hundreds of thousands losing their jobs in the tourism industry. Tourism constitutes 10 per cent of the US economy, and apparently employs one million persons in Europe alone.

Businesses will clearly be changing their practices. There is already a trend to limit business travel, and to rethink the global procurement ideas that had become such a part of the globalizing economy. The events of September suggest a whole new layer of risks on business activity, and thus a higher risk premium is considered necessary for an appropriate rate of return; therefore the capital value of investments decline. Other activities, such as the economics of skyscrapers and transportation, are being re-thought. We have seen the immediate response of huge public expenditures, and a shift in the budget priorities of major nations, obviously including the nation that was attacked, the United States. 
In responding to these challenges, governments may find it necessary, and are certainly tempted, to constrain certain types of liberties that had been taken for granted, including some liberties that are essential to the working of markets (such as freedom of information and freedom of movement of individuals in relation to their business needs). We are also seeing a considerable nervousness about other events in the world: a factory blowing up in Toulouse France, and a Russian plane that is somehow blasted out of the sky over the Black Sea. These may be relatively normal accidents, but there is the tendency to wonder whether they might be part of a broader pattern of terrorist activity.

Perhaps one of the few bright spots in this landscape is that it seems to have created an international relations atmosphere that demands greater international cooperation. Perhaps, some might say, this is a wake up call to nations that might otherwise be tempted to indulge in unilateral measures without consideration of impacts on foreign societies. Of course it remains to be seen how long this new attitude toward international cooperation will persist. The other side of that coin is the utilization by special interests of the 'excuse of terrorism' to obtain special government funding allotments and to pursue other objectives that long preceded the September events, but now are rationalized as more important because of the need to counter terrorism.

Indeed, some of these activities seem to be profoundly affecting basic market economics principles, with the surge in government spending leading some to rethink the advantages of reliance on market and non-government institutions in society. In terms of trade policy, the whole idea of 'subsidies' may need to be rethought, as well as other principles of the world trade system.

\subsection{Importance of institutions for markets}

Economists generally, and more particularly Nobel Prize winning economists over the past decades, ${ }^{2}$ have often stressed the importance of institutions in the functioning of markets. Without an institutional framework, markets simply will not work. This framework can be comprised of various types of human institutions, such as practice, culture, particular bidding structures, etc. But legal rules are the most prominent of the institutional frameworks for markets. Thus, since legal rules almost always require governments, governments become central to markets (contrary to some statements by ideologically oriented persons who think less government is always better).

The previous most important innovation of institutions regarding international economic relations was the development of the Bretton Woods institutions, starting with the 1944 Bretton Woods Conference, and running through to the end of the 1940s. The 1944 Conference created the World Bank and the International Monetary

2 See North, D. C., Institutions, Institutional Change, and Economic Performance, Cambridge: Cambridge University Press, 1990; Coase, R. H., The Firm, the Market, and the Law, Chicago: University of Chicago Press, 1998. 
Fund, and the negotiations for a similar organization for trade (the third leg of the tripod of Bretton Woods institutions) continued through 1948. But as is commonly known, the potential International Trade Organization, or ITO (of the Havana Charter of March 1948) never came into effect, largely because of objections in the US Congress. However, the General Agreement on Tariffs and Trade (GATT) was in place for some very special diplomatic and national constitutional reasons (particularly the structure of the United States Constitution and its authorities delegated to the President). The GATT continued, therefore, to play a role that gradually became enhanced, as it filled the vacuum left by the failure of a trade organization to come into being. This role became increasingly important as decades wore on, but it also became clear, with the passage of time, that the GATT had substantial institutional defects ${ }^{3}$ that made it harder and harder for it to cope with some of the new issues being thrust upon it.

Thus, in the Uruguay Round, which added several huge new subjects to the trade system competence (especially intellectual property and services), it was considered necessary to create a new organization, the WTO. All of this is familiar ground. One of the lessons of this is the important contribution that was made by the institutional fathers of the Bretton Woods system (including all three legs of the stool). The basic objective of these persons was to prevent another world war of the catastrophic nature of World War II. In that respect, the system can claim a considerable amount of success. Clearly, the institutions created have contributed to the prevention of a cataclysmic World War III. But one of the key questions is whether those institutions are still appropriate to the kinds of problems that are being faced by the world today, including financial crises, tendencies towards partitioning markets, both by nation state protectionism and excessive regionalism, and, of course, the operation of terrorism, and how that affects market institutions.

\subsection{Institutional philosophy}

At this point, I would like to turn for assistance to some outstanding academics and their writings. In particular, I would like to broaden the context of this paper, to look at some of the thinking about the institutions that are critical for international markets.

In particular, I refer to an extraordinary lecture delivered by Professor Robert Keohane, of Duke University, who was the President of the American Political Science Association for the year 2000. In that capacity, he delivered the annual Presidential lecture, which is a careful, long, thoughtful, and I must add, very dense

3 See, for example, Jackson, J. H., The World Trading System: Law and Policy of International Economic Relations, 2nd edn, Cambridge, MA: MIT Press, 1997; Jackson, J. H., The Jurisprudence of the GATT and the WTO: Insights on Treaty Law and Economic Relations, New York: Cambridge University Press, 2000; Jackson, J. H., The World Trade Organization: Constitution and Jurisprudence, Chatham House Papers, London: Royal Institute of International Affairs, 1998. 
speech. ${ }^{4}$ I cannot possibly discuss very much of this lecture, although I commend it to persons who would like an extraordinarily thorough overview of political science with regard to this subject, but I think there are two key points that need to be considered. One is a list that Professor Keohane puts forward of prerequisites for successful social institutions. Second, is the importance of norms, or rules, as part of the institutional structure for enhancing the potential success of markets.

\section{(i) Prerequisites for successful social institutions}

Professor Keohane outlines a series of prerequisites for social institutions, relying in part on other thinkers, such as Jurgen Habermas. ${ }^{5}$ From Habermas, Keohane notes the importance of 'discourse', generally meaning very wide participation with open communication and 'collective reflection'. These elements of an institution, he and other profound thinkers suggest, are exceedingly important to the durability and success of social institutions in the kind of world that we are living in today (with extremely broad and fast communication, and a relatively high world-wide level of education). He outlines considerable detail about this, but for our purposes, I mention three procedural criteria that he sets forth:

First, he stresses the importance of accountability and recognizes that this may lead to ideas of government being close to its constituents, or what is sometimes termed 'subsidiarity'.

Second, he notes the importance of participation that is open to all, particularly in the process of rule-formulation, but maybe also in the process of rule-application.

Thirdly, he notes the importance of persuasion in a thoughtful and non-polemic way. He notes that there is a necessity for institutionalized procedures to ensure that this type of persuasion can have its important impacts.

\section{(ii) The importance of rules or norms}

The second major category that many thinkers (including Professor Keohane) stress is the importance of rules or norms. These rules have considerable importance to markets, particularly markets that are based on decentralized decision-making of private enterprises, which number in the millions. As I myself have written, these market participants find it more efficient to have a certain degree of predictability and stability, ${ }^{6}$ which rules can provide, and thus reduce somewhat the risk of their entrepreneurial decisions. Keohane and the thinkers that he relies on note that the rules should have certain characteristics, such as hindering manipulation, allowing third-party discourse, providing for precedents - and thus predictability, stability, and being created through impartial processes.

4 Keohane, R., 'Governance in a partially globalized world', Presidential address, American Political Science Association, 2000, The American Political Science Review, March 2001.

5 Habermas, J., Between Facts and Norms: Contributions to a Discourse Theory of Law and Democracy, Cambridge, MA: MIT Press, 1996.

6 See supra note 3. 


\section{The WTO as an institution for the enhancement of world market activity}

There has been much discussion recently about the appropriate scope of WTO activity, or the dimensions of its 'competence'. Occasionally, people have said that the WTO has become overloaded and threatens to be further overloaded, and these persons (ignoring the fact that overloading is mostly a function of lack of government will to provide the necessary resources) sometimes advocate that the WTO return to its 'central responsibility, which had been confined to border measures that limited trade'. This view is a serious misunderstanding of the history of the GATT.

From the very beginning, the GATT text provided great attention to internal government measures affecting trade, as well as border measures. Article III paragraph 4 is an extraordinarily broad and sweeping clause, requiring nondiscriminatory treatment ('National Treatment') in the application of virtually all types of internal economic regulation, as affecting imports. In the early decades of the GATT, most negotiating attention was upon tariff reduction, and this process was extraordinarily successful. But by the 1970s, it had become clear that tariffs were no longer the really important policy issues for trade liberalization. There had been a substantial shift to 'non-tariff barriers' (NTBs), partly as an alternative to low tariffs sought by constituencies in order to limit competition, and thus give them greater shares of the producer surplus.

Therefore, it became clear that attention toward internal government measures would have to be increased. Thus in the Tokyo Round a great deal more than usual attention was put upon non-tariff barrier measures, resulting in a series of side codes (partly because of the difficulty of amending the GATT) that addressed a variety of such non-tariff measures, including subsidies, customs valuation, product standards, government procurement, etc. Likewise, the Uruguay Round went considerably further in this regard, pulling together almost all of these side codes into a 'single package' becoming mandatory on all Members of the WTO. This surely has been a very major step in the right direction of providing the necessary institutional framework for markets to work. But it has not been without pain. Such attention to the internal regulatory activities of governments has brought its share of backlash. It has also induced some advocates, some of whom are clearly motivated by the desire to prevent competition and market forces from operating to their short-term detriment, to object to further addition of subject matters underneath the WTO umbrella.

There may indeed be arguments why certain additional subjects should not be brought under the WTO umbrella, but those arguments are not reasonably based on some a priori notion that the GATT/WTO has certain 'inherent limitations' to its appropriate competence. In fact, when you read the GATT and other Uruguay Round texts, including Article III, and when you consider the way the world's 'globalized economy' has been developing, it becomes reasonably clear that virtually every economic regulatory subject regarding activity and economic influences that cross nation state borders (and virtually all do) could logically be included in the 
WTO reach. There needs to be some kind of international cooperative institutional mechanism to address these regulatory problems in a way that nation states are increasingly unable to do successfully. Thus, logically, subjects such as competition policy, investment rules, labor standards, environmental standards, etc. could be subjects for the WTO competence.

But there are also reasons not to bring such subjects under the WTO umbrella; reasons that are not based on an a priori rigid, taxonomic view of the WTO institution, but rely more on a pragmatic consideration of the resources and competence available in the WTO as an organization and the limitations on those resources, as well as ideas about whether the 'inside the Geneva beltway' mindset is capable, at least in the near term, of addressing some of the more complex, and possibly ambiguous, policies involved. In addition, of course, some of the subject matters, if brought into the WTO tent, could be utilized in a way that has little to do with the basic purposes of liberalizing trade while balancing other social policies. In short, there is a danger of the misuse of some of these subjects for protectionist reasons.

Indeed, some rethinking could be important for the questions of 'single package' and 'most-favored nation'. There are some issues that increasingly need to be addressed by an international institution of some sort, but there is little pragmatic reason to require all $142+$ WTO Members to embrace rules for those subjects. Maybe half the nations would provide more than 90 per cent of the market activity relating to those subjects, and that half of the Membership would provide an important critical mass for a core group for addressing some issues (as exemplified by telecommunications and financial services). Maybe competition policy, investment, and the environment are other issues ripe for such consideration, and maybe some rethinking is necessary for the intellectual property area. All of these are conjectures, and it is also the case that it may be necessary, particularly in the face of a too-rigid consensus approach to decision making, or because of the risks of misuse of WTO power in certain circumstances, to go elsewhere to some other kinds of institutions, maybe some of which might be loosely affiliated with the WTO. In any event, there are many different kinds of institutional structures that could be considered, and attention to these broader, systemic issues of the world trading system is vitally needed.

Much of the above also relates to the question of 'sovereignty', which is a concept that is certainly much abused. Indeed, this concept has been characterized as 'organized hypocrisy' by an outstanding academic who has written extensively on this subject. ${ }^{7}$ Often, sovereignty is invoked for special interest-pleading that has very little to do with the true issues of institutional structure for international economic relations. Basically, it is my view that the real issue of 'sovereignty' is the question of allocation of decision-making authority. It is the question of whether a certain kind of decision should be made in Geneva, Washington DC, Sacramento, or

7 Krasner, S. D., Sovereignty: Organized Hypocrisy, Princeton, NJ: Princeton University Press, 1999. 
Berkeley (or in the European context: in Geneva, Brussels, Berlin, at the Länder (state) level, or finally at the city level). This is a subject for other discussions and writings ${ }^{8}$ but it is important to recognize that it is vitally intertwined with the question of institutional development of the WTO.

At this point, it is necessary to turn to the WTO dispute settlement system.

\section{The WTO dispute settlement system}

One of the more admired attributes of the GATT was its dispute settlement system and accompanying procedures. The original text of the GATT included very little about dispute settlement, but over more than 30 years of experience and trial and error, the GATT dispute settlement procedures developed into a remarkably sophisticated and quite effective system, which helped create a sense of implementation of the results of the findings of that system. ${ }^{9}$

The new WTO dispute settlement system, essentially established in the 'Dispute Settlement Understanding' (which is Annex 2 of the WTO Charter ${ }^{10}$ ) is a further progression of the GATT system towards 'rule orientation'. ${ }^{11}$ As indicated in Part I of this article, many thinkers about human institutions, especially as they relate to markets, realize the values of a rule orientation system. These values include:

1 A sense of fairness that the players or participants in the system can expect to be treated even-handedly, and relatively impartially, so that they will be operating on a 'level playing field' of trade policy. Thus, developing and least-developed countries have a chance for some redress of grievances that result from countries (even large, developed countries) departing wrongfully from the rules. Especially in an era of globalization and terrorist peril, such a sense of fairness is significant, partly as an antidote to 'pure power exercise', or what has been termed 'poweroriented diplomacy' rather than rule-oriented diplomacy.

2 A second value recognized by many perceptive thinkers is that a rule-oriented system tends to reduce, at least moderately, the risks that entrepreneurs take and gives those entrepreneurs a higher degree of security, stability, and predictability.

8 See Jackson, J. H., 'The Great 1994 Sovereignty Debate: United States Acceptance and Implementation of the Uruguay Round Results', Columbia Journal of Transnational Law, 36 (1997): 157-188 and Jackson, J. H., 'Sovereignty, Subsidiarity, and the Separation of Powers: The High Wire Balancing Act of Globalization', Conference Proceedings, University of Minnesota Law School, Conference to Honor Professor R. E. Hudec, September 2000; Cambridge University Press, forthcoming.

9 See Jackson, J. H., The World Trading System: Law and Policy of International Economic Relations, 2nd edn, Cambridge, MA: MIT Press, 1997, chapter 4; Hudec, R. E., Enforcing International Trade Law: The Evolution of the Modern GATT Legal System, Salem, N.H.: Butterworth Legal Publishers, 1993.

10 The phrase 'WTO Charter' refers to the Agreement Establishing the World Trade Organization.

11 See, for example, Jackson, The World Trading System, p. 109; Jackson, J. H., The World Trade Organization: Constitution and Jurisprudence, Chatham House Papers. London: Royal Institute of International Affairs, 1998, chapter 4. 
Another way of expressing this is that such a system reduces the 'risk premium' of a variety of economic decisions, including investment decisions. A reduction in the risk premium means that the risk taker can accept a somewhat lower return on his investment or other decision, and in the aggregate, when this is a situation generally prevailing, this reduction in the risk premium is a reduction in transaction costs as well. Altogether, these factors would normally represent a substantial increase in the efficiency of economic activity, and thus, an increase in world welfare.

3 However, the dispute settlement system faces a degree of unease from many of the 'old hands' and experienced participants. It is clear that an effective dispute settlement system has certain impacts on 'sovereignty'. Nation states find themselves constrained as to what they may want to do with respect to their internal policies, because certain measures may be inconsistent with the international rules, and a dispute settlement system can so declare, making it much more difficult for an errant nation state to take such inconsistent measures. Yet, clearly there is a benefit to be obtained, as mentioned above, which can be considerably greater than the small inroads on sovereignty.

As businesses begin to accept the effectiveness of a rule-oriented system, and begin to take account of it in their strategic planning, it generally seems that such businesses see a value in the system, even though they may feel that they have less opportunity to affect their own nation's activities. The rules and the method of implementing rules (such as a dispute settlement system) also have an impact on citizens, and this impact is growing as more and more issues of internal government regulation fall under the umbrella of the WTO system.

So far, the reform of the dispute settlement system represented by the new procedures of the WTO and the Uruguay Round text appear to be extraordinarily successful. As this is written, in November 2001, there have been, in the period of the WTO's existence (slightly less than seven full years), approximately 240 complaints brought under the dispute settlement system, about 53 of which have resulted in concrete findings, as expressed in a report, either of First Level Panels, or of the Appellate Body (a new part of the dispute settlement procedure introduced by the Uruguay Round text). Overall, this jurisprudence constitutes somewhat more than 11,000 pages, and, in fact, is enormously rich. Yet, there are worries that the dispute settlement system is too secretive, and lacks transparency. There are also worries that it is not open to participation of important players, including non-governmental entities. The 'government-to-government' approach of the dispute settlement system is what particularly annoys some of the observers, although there are arguments to support that characteristic of the system. Sometimes diplomats find themselves as frustrated as national sovereigns in the parameters imposed upon them by the treaty texts as implemented by the dispute settlement system.

However, some of the smaller countries that are Members of the WTO are finding great comfort in the more rigorous and more rule-oriented dispute settlement procedures that have been introduced by the Uruguay Round text. Some of the least- 
developed countries have found some measure of success in a few cases, even against very large and powerful trading Members. ${ }^{12}$

Furthermore, although there are a few notorious examples of non-compliance in relation to some of the completed dispute settlement reports, on the whole there appears to be a very good record of compliance, including compliance by some of the most powerful nations who are utilizing the system. In addition, many of the complaints brought are being settled or otherwise disposed, on bases that appear to be amicable, between the disputing parties. This is a good sign that the dispute settlement system is playing a more efficient role in providing for dispute settlement; particularly dispute settlement that is consistent with the overall rules.

The jurisprudence of the new system is mostly reflected by an amazing group of reports by the Appellate Body in approximately 40 of the finished cases. The Appellate Body has brought a sense of rigor and deep analysis that goes well beyond the jurisprudence that developed during the more than three decades of the GATT, and indeed, may go beyond the record of any international law tribunal known in history. In that jurisprudence, the Appellate Body divisions are seen to struggle with a variety of very difficult concepts about reconciling, on the one hand, the need for allowing nation states a 'margin of appreciation' or a measure of 'deference', so that they can go about their very difficult tasks of governing in a way that can support the lifestyle and welfare goals of their constituents. On the other hand, the Appellate Body is struggling with the importance of rule integrity in the WTO system. In a case such as the Shrimp-Turtle case, one can almost visualize the furrowed brows of the Appellate Body Members as they struggle with difficult concepts, balancing important social policies that often pose dilemmas or trade-offs, and arriving sometimes at language that is extraordinarily nuanced and delicate, sometimes discussed into late hours of the evening. ${ }^{13}$

However, there are manifestations within the processes of the WTO that have resulted in strident criticism of the dispute settlement system, some of which criticism apparently indicates a lack of understanding of a rule-oriented system or the processes by which a judicial-type body needs to operate. ${ }^{14}$ The procedures clearly need attention, and the final Ministerial conference of the Uruguay Round at Marrakech, Morocco in April 1994, decreed that there should be an overall review of the dispute settlement system within the first four years of its existence. Unfortunately, the Members of the WTO have not been able to achieve this review. Various countries have put forward lists of reforms that they would like to see (or at least see discussed) and an amalgamation of such lists could easily number more

12 Appellate Body Report, US - Restrictions on Imports of Cotton and Man-Made Fibre Underwear (Costa Rica v. United States), WT/DS24/AB/R, adopted 25 February 1997.

13 Appellate Body Report, United States - Import Probibition of Certain Shrimp and Shrimp Products, WT/DS58/AB/R, adopted 6 November 1998, para 121. And United States - Import Prohibition of Certain Shrimp and Shrimp Products, Recourse to Article 21.5 of the DSU by Malaysia, WT/DS58/AB/RW, adopted 22 October 2001.

14 Appellate Body Report: EC-Measures Affecting Asbestos and Asbestos-Containing Products, WT/DS135/AB/R, adopted on 12 March 2001. 
than 200 items. Many of these items however, are, relatively, matters of 'finetuning', yet there are some important reform issues for the dispute settlement system that need serious attention. One of the concerns that disinterested observers can have about the WTO is that the relative paralysis of the non-dispute settlement parts of the organization is also inhibiting the evolution and improvements that are needed by the dispute settlement system. There is discussion of the size and nature of the Appellate Body, for example (Should it be constituted of full-time Members rather than part-time? Should it be enlarged?). There is also discussion of whether the First Level Panels, which are now appointed ad hoc from a variety of personnel (many of whom are officials of Member Governments, and thus are generally not paid for their extra services to the WTO dispute settlement system) should be reformed into a permanent roster-type arrangement similar to that which the Appellate Body has.

In some of these struggles, one can detect a certain ambivalence about the new dispute settlement procedures, even among the major powers, which were rather ardent proponents of the reforms developed in the Uruguay Round, but may now be back-tracking slightly because of some of the political troubles that specific dispute results have had for them.

To some extent, these problems mentioned above can be discussed as parts of a broader 'power struggle' between the dispute settlement system and its officials, on the one hand, and the diplomat/negotiators and their efforts, on the other hand. To the extent that the diplomatic/negotiation side of the WTO becomes increasingly unable to perform its obligations (decisions and negotiation of new rules), there is a strong temptation by various actors within the system to take their problems to the dispute settlement system, and this, in turn, may be posing excessive burdens on the dispute settlement system, in the sense of causing the dispute settlement system to address issues and legal problems that are not particularly appropriately addressed in a rule-applying, or judicial-type institution. Many of these issues really need to be solved by the negotiators, as part of a rule-making process, rather than a dispute settlement/judicial process.

\section{Developing countries and the newly established Advisory Centre on WTO Law as part of the WTO system}

One of the characteristics of the activity under the dispute settlement system so far in the WTO has been the remarkable amount of developing country participation. Of course, developing countries are sometimes the target of complaints by developed countries. But many developing countries have, themselves, become complainants against other Members of the WTO, including some of the important industrialized country Members. This participation of the developing countries in this system is, in the opinion of many, absolutely vital to the long-term durability and effectiveness of the WTO dispute settlement system, and, therefore, probably of the WTO itself. If the WTO is seen to be tilted, or unbalanced with respect to an important attribute 
of Membership, namely access to the dispute settlement procedures, this undermines the sense of fairness and, to some extent, the essential value of being a Member. The dispute settlement system thus offers considerable opportunity for fuller participation as Members in the WTO system, and that is already manifest by the number and distribution of cases brought.

However, experience is showing that participation in the dispute settlement process has some very considerable costs, costs that are not easily borne by developing countries, and particularly the least-developed countries. There are several dimensions to these costs. First, many of the developing countries that would like to participate in the dispute settlement process, find that they do not have the expertise in their government service and ministries to do effective work in connection with the WTO dispute procedures. For a while, those procedures either prohibited or greatly inhibited the use by nation states of private counsel, hired to work with them on cases, and to present cases in the WTO procedures. But as of several years ago, it appears that that hurdle has been overcome, and now it is quite common for governments, especially smaller governments and developing country governments who do not have 'in house expertise', to retain outside counsel to help them. But this, too, has its costs. The fees for such help can be quite onerous for poorer countries. The very best help, of course, can command fees commensurate to their work with other clients, including very large corporations, large and rich governments, etc. Thus, to obtain the benefit of these highly skilled persons, the developing countries find they must pay significant sums. In some cases, they feel that these sums are beyond their abilities to provide, and, yet, they feel they have rights to affirm, and need the legal profession's assistance.

Many nation states have already realized this phenomenon in connection with their own internal legal systems, and have developed institutions of 'legal aid', for providing trained lawyers' assistance to the poor. By analogy therefore, it has seemed to some inspired leaders within the WTO that a similar arrangement could be developed for the WTO dispute settlement system. And thinking along those lines has indeed resulted in the new institution being inaugurated, namely the Advisory Centre for WTO Law, as a center to assist developing countries. Under the rules of this Centre, developing countries will have access to assistance from an internal, small legal staff of the Advisory Centre, and in some cases will receive assistance to hire other private attorneys to help them. The Advisory Centre will charge fees for this help, but the fees will be scaled down, according to the wealth of the country seeking aid. In some cases, for the very poorest of the countries being assisted, the fees may actually be zero.

One of the ingenious facets of the procedures established by the new Advisory Centre is that it combines its assistance for advocacy with a moderate mission of training. Part of this training can be accomplished by asking an assisted country to provide a person who will be a sort of 'intern', working with the Advisory Centre staff on the case for his or her country, and thus receiving experience in that process. This type of capacity-building is certainly welcome, and some people believe that the 
Advisory Centre will also engage in some other types of training activities along the same line.

Some of the issues facing the new Advisory Centre will not be easy to handle. The Centre will obviously need to understand some of the broader trends of the WTO negotiating and dispute systems, so as to better serve its clients in its advocacy. This is because the panelists or Appellate Body Members that will be responding to legal questions, will also need to respond with a knowledge of the context of those questions, and this necessitates an understanding of where the WTO institution currently stands, and where it is headed.

Also, the Advisory Centre will undoubtedly be called upon to make recommendations about certain reforms, presumably focusing, or even confining, its attention to reforms about which it has the most expertise, namely the procedures of the dispute settlement system.

However, in carrying out its responsibilities, particularly in connection with the broader institutional setting of the WTO and providing expertise in relation to proposals for reforms, the Advisory Centre will necessarily need to separate its advocacy role rather strongly from its policy preferences. It has an obligation to its clients under professional ethics (some of which will be newly developed as part of the procedures of the WTO) to be a vigorous advocate, and utilize strong arguments on behalf of its clients. But it will need to consider, probably on a case-by-case basis, the degree to which its advocacy role is consistent with expressions of policy preferences or suggestions about reform of the dispute settlement system. Needless to say, the Advisory Centre, in this respect, will have some delicate tasks ahead of it, but there is every confidence that its structure, personnel, and leadership will be able to cope with these problems and dilemmas.

Finally, let me draw this article to a close with an expression of several simple propositions. Clearly, the dispute settlement system is very central, and extremely important for the WTO and for the WTO's future as an institution that helps make world markets work. It is also clear that the strength of this WTO dispute settlement system depends on a world perception that it is fair and even-handed. And that perception, in turn, depends on the ability of all Members of the WTO to have essential access to the dispute settlement process, even when they lack resources to do so on their own basis. Thus, the Advisory Centre will play an extremely important role in assisting the relatively new organization of the WTO to better achieve some of its purposes and goals, which, in turn, are so vitally needed in the type of world that is developing at a rapid pace.

\section{References}

Appellate Body Report (1997), 'US - Restrictions on Imports of Cotton and Man-Made Fibre Underwear' (Costa Rica v. United States), WT/DS24/AB/R, adopted 25 February.

- (1998), 'United States - Import Prohibition of Certain Shrimp and Shrimp Products', WT/DS58/AB/R, adopted 6 November, para, 1212001. 
114 JOHN H. JACKSON

(2001), 'EC - Measures Affecting Asbestos and Asbestos-Containing Products', WT/DS135/AB/R, adopted on 12 March.

- (2001), 'United States - Import Prohibition of Certain Shrimp and Shrimp Products', Recourse to Article 21.5 of the DSU by Malaysia, WT/DS58/AB/RW, adopted 22 October.

Coase, R. H. (1988), The Firm, the Market, and the Law, Chicago: University of Chicago Press.

Habermas, J. (1996), Between Facts and Norms: Contributions to a Discourse Theory of Law and Democracy, Cambridge, MA: MIT Press.

Hudec, R. E. (1993), Enforcing International Trade Law: The Evolution of the Modern GATT Legal System, Salem, N.H.: Butterworth Legal Publishers.

Jackson, J. H. (1997), The World Trading System: Law and Policy of International Economic Relations, 2nd edn, Cambridge, MA : MIT Press.

— (1997), 'The Great 1994 Sovereignty Debate: United States Acceptance and Implementation of the Uruguay Round Results', Columbia Journal of Transnational Law, 36: 157-188.

- (1997), The World Trading System: Law and Policy of International Economic Relations, 2nd edn, Cambridge, MA: MIT Press, chapter 4.

— (1997), The World Trading System, Cambridge, MA : MIT Press, p. 109

- (1998), The World Trade Organization: Constitution and Jurisprudence, Chatham House Papers. London: Royal Institute of International Affairs.

- (2000), The Jurisprudence of the GATT and the WTO: Insights on Treaty Law and Economic Relations, New York: Cambridge University Press.

- (2000), 'Sovereignty, Subsidiarity, and the Separation of Powers: The High Wire Balancing Act of Globalization', Conference Proceedings, University of Minnesota Law School, Conference to Honor Professor Robert E. Hudec, September. Forthcoming, Cambridge University Press.

Keohane, R. (2001), 'Governance in a partially globalized world', Presidential address, American Political Science Association, 2000', The American Political Science Review, March.

Krasner, S. D. (1999), Sovereignty: Organized Hypocrisy, Princeton, NJ: Princeton University Press.

North, D. C. (1990), Institutions, Institutional Change, and Economic Performance, Cambridge: Cambridge University Press. 